\title{
Genetic parameters of dairy traits in the Alpine and Saanen goat breeds
}

\author{
Sophie Bélichon ${ }^{\mathrm{a}}$, Eduardo Manfredi ${ }^{\mathrm{b} *}$, Agnès Piacère ${ }^{\mathrm{c}}$ \\ ${ }^{a}$ Caprigène France. Agropole, route de Chauvigny, \\ 86500 Mignaloux-Beauvoir, France \\ b Station d'amélioration génétique des animaux, Institut national de la recherche \\ agronomique, BP 27, 31326 Castanet-Tolosan cedex, France \\ c Institut de l'élevage, 149, rue de Bercy, 75595 Paris cedex 12, France
}

(Received 4 May 1999; accepted 16 August 1999)

\begin{abstract}
Genetic parameters for milk, fat and protein yields, and fat and protein contents, were estimated for the Alpine and Saanen goat breeds using an animal model. Edited data included first lactations of 33431 Alpine and 20700 Saanen goats kidding in 1996 and 1997. Heritability values ranged from 0.32 to 0.40 for yields and from 0.50 to 0.60 for solid contents. The main feature observed on genetic correlations was a low genetic opposition between milk yield and fat content (about -0.17) with a high genetic association between fat yields and fat contents (up to +0.56 ). Although the differences between genetic parameters of both breeds were rather low, the estimates suggest a higher potential for genetic progress in protein content and protein yield in the Alpine breed, and a higher potential for joint genetic progress in milk yield and fat content in the Saanen breed. (C) Inra/Elsevier, Paris
\end{abstract}

goat / dairy production / genetic parameters

Résumé - Paramètres génétiques de caractères laitiers des races Alpine et Saanen. Les paramètres génétiques des quantités de lait, de protéines et de matière grasse et les taux protéique et butyreux sont estimés pour les races Alpine et Saanen en utilisant un modèle animal. Les données correspondent aux premières lactations de 33431 (Alpine) et 20700 (Saanen) chèvres durant les campagnes 1996 et 1997. Les héritabilités varient de 0,32 à 0,40 pour les quantités et de 0,50 à 0,60 pour les taux. Les résultats marquants sont la corrélation génétique modérée $(-0,17)$ entre la quantité de lait et le taux butyreux et la forte association $(0,56)$ entre la quantité et le taux de matières grasses. Si les différences entre les paramètres génétiques des deux races sont faibles, elles suggèrent que le progrès génétique potentiel pour la quantité et le taux de protéine est plus élevé en race Alpine alors que l'amélioration simultanée de la quantité de lait et du taux butyreux est plus facile en race Saanen. (c) Inra/Elsevier, Paris

caprins / production laitière / paramètres génétiques

\footnotetext{
* Correspondence and reprints

E-mail: manfredi@toulouse.inra.fr
} 


\section{INTRODUCTION}

Since 1985, goat selection in France has been oriented toward an improvement of protein yield and protein content (PY and PC, respectively) because goat milk is mainly used for cheese production and protein content was a limiting factor in the highly productive Alpine and Saanen breeds. The selection programme relies on the use of milk recording and artificial insemination in an open nucleus [7]. At present, realised genetic gains for PC and PY allow the selection objective to be widened by including fat yield and fat content (FY and FC, respectively). The knowledge of genetic parameters is necessary to optimise the relative weights to be given to dairy traits in the new objective. However, last on-farm estimates available [3] were obtained using a sire model on data collected between 1982 and 1985. This study aims at updating the estimates of genetic parameters for milk, fat and protein yields, fat and protein contents, in the Alpine and Saanen populations using an animal model.

\section{MATERIALS AND METHODS}

\subsection{Data}

First lactation records of Alpine and Saanen goats kidding between 1 September 1995 and 31 August 1997 were obtained from the national milk recording data base located at the CTIG (Processing Centre of Genetic Information). According to the current genetic evaluation procedure, yields were partially corrected for lactation length (LL) either by a coefficient equal to $250 /(60+$ LL) for LL shorter than 250 days or by truncation at the 250 th day when LL was longer. Data editing excluded records from goats who were over 30 months of age and records from herd-year combinations with fewer than five first lactating goats or less than $15 \%$ of daughters sired by artificial insemination bucks. This last condition aimed at insuring sufficient genetic connection between herds. Indeed, when genetic differences among herds are suspected, and, therefore, when part of the genetic variability may be confounded with the environmental herd effect, deleting the disconnected herds from the studied samples is advised [4, 10]. Pedigrees were traced three generations back. Samples of 20700 Saanen and 33431 Alpine goats, with 19940 and 43555 ancestors, respectively, were kept for the analysis. Samples should be representative of the open selection nucleus populations. Their main characteristics are given in table $I$.

\subsection{Methods}

Bivariate analyses were carried out for all combinations of the five dairy traits (ten analyses). The animal model used was the same for all combinations:

$$
\mathbf{y}=\mathbf{X} \beta+\mathbf{Z} \mathbf{u}+\mathbf{e}
$$

where $\mathbf{y}$ is a vector of records $n \times 2$ rows (for $n$ recorded goats), $\beta$ is a vector of fixed effects (herd-year, year-age at kidding and year-month at kidding), $\mathbf{u}$ is a random vector of additive genetic effects, $\mathbf{X}$ and $\mathbf{Z}$ are the corresponding 
Table I. Structure and average performances (average, av., and standard deviations, $\sigma$ ) of the samples studied.

\begin{tabular}{llrr}
\hline & & Alpine breed & Saanen breed \\
\hline Number of: & records & 33341 & 20700 \\
& herd-year combinations & 1168 & 713 \\
& AI sire-year combinations & 164 & 111 \\
& other sire-year & 2619 & 1834 \\
\hline \multirow{2}{*}{ av. $(\sigma)$ of: } & milk yield $(\mathrm{kg})$ & $648(167)$ & $676(182)$ \\
& protein yield $(\mathrm{kg})$ & $19.9(5.1)$ & $19.9(5.3)$ \\
& protein content $(\mathrm{g} / \mathrm{kg})$ & $30.8(2.5)$ & $29.6(2.1)$ \\
& fat yield $(\mathrm{kg})$ & $22.7(6.3)$ & $21.8(6.5)$ \\
& fat content $(\mathrm{g} / \mathrm{kg})$ & $35.1(4.6)$ & $32.3(4.2)$ \\
\hline
\end{tabular}

incidence matrices (identical for both traits) and $\mathbf{e}$ is a random vector of residual effects.

Expected values of records are defined as:

$$
E(\mathbf{y})=\left(\mathbf{I}^{*} \mathbf{X}\right) \beta
$$

where I is an identity matrix. Expected values of random effects are assumed to be null.

Covariance matrices are defined as:

$$
\operatorname{Var}(\mathbf{u})=\mathbf{G}^{*} \mathbf{A}, \operatorname{Var}(\mathbf{e})=\mathbf{R}^{*} \mathbf{I}, \operatorname{Var}(\mathbf{y})=\mathbf{G}^{*} \mathbf{Z} \mathbf{A} \mathbf{Z}^{\prime}+\mathbf{R}^{*} \mathbf{I}
$$

where * denotes direct products, $\mathbf{A}$ is the relationship matrix, and $\mathbf{G}$ and $\mathbf{R}$ are covariance matrices between both traits for the additive genetic and residual effects, respectively. Covariances among $\mathbf{u}$ and $\mathbf{e}$ are assumed to be null.

For each year, seven classes for age at kidding were defined $(10,11,12,13$, 14, 15-18 and 19-30 months old) and six classes for month at kidding were defined (monthly between January and April, from September to December and from May to August).

The covariance components were estimated using VCE 4.2 .5 by the multivariate REML method based on analytical gradients [8]. The choice of bivariate analyses was made according to computing facilities available. Consequences of estimating the covariance components through bivariate analyses could not be evaluated but we verified the stability of the multiple variance estimates obtained for each trait, and also the eigenvalues of the additive genetic covariance matrix which was positive-definite.

\section{RESULTS AND DISCUSSION}

\subsection{Genetic variability}

The estimates of variance components were relatively stable throughout the bivariate analyses, with maximum differences between the four heritability 
Table II. Estimates of genetic and phenotypic standard deviations ( $\sigma_{\mathrm{p}}$ and $\sigma_{\mathrm{g}}$, respectively), heritability ( $h^{2} \pm$ estimates of standard error SE, in \%), and genetic coefficient of variation $\left(\mathrm{CV}_{\mathrm{g}}=\sigma_{\mathrm{g}} / \mathrm{av}\right.$., in $\%$, with av. the phenotypic average of the samples).

\begin{tabular}{|c|c|c|c|c|c|c|c|c|c|}
\hline \multirow[b]{2}{*}{ Traits } & & \multicolumn{4}{|c|}{ Alpine breed } & \multicolumn{4}{|c|}{ Saanen breed } \\
\hline & & $\sigma_{\mathrm{p}}$ & $\sigma_{\mathrm{g}}$ & $h^{2} \pm$ s.e. & $\mathrm{CV}_{\mathrm{g}}$ & $\sigma_{\mathrm{p}}$ & $\sigma_{\mathrm{g}}$ & $h^{2} \pm$ s.e. & $\mathrm{CV}_{\mathrm{g}}$ \\
\hline Milk & $\mathrm{kg}$ & 133 & 77.1 & $34 \pm 1.5$ & 11.8 & 144 & 81.6 & $32 \pm 1.7$ & 12.1 \\
\hline PY & $\mathrm{kg}$ & 3.80 & 2.28 & $36 \pm 1.5$ & 11.5 & 3.96 & 2.31 & $34 \pm 1.7$ & 11.5 \\
\hline $\mathrm{PC}$ & $\mathrm{g} / \mathrm{kg}$ & 2.27 & 1.72 & $58 \pm 1.5$ & 5.5 & 1.94 & 1.37 & $50 \pm 1.8$ & 4.7 \\
\hline FY & $\mathrm{kg}$ & 4.99 & 3.02 & $37 \pm 1.5$ & 13.2 & 5.08 & 3.21 & $40 \pm 1.8$ & 14.7 \\
\hline $\mathrm{FC}$ & $\mathrm{g} / \mathrm{kg}$ & 4.04 & 3.08 & $58 \pm 1.5$ & 8.8 & 3.83 & 2.96 & $60 \pm 1.8$ & 9.3 \\
\hline
\end{tabular}

values varying between 0.2 and $0.3 \%$ in most cases, with extreme values of $0.1 \%$ for FY in the Alpine breed and $0.4 \%$ for FY in the Saanen breed. The average values of these estimates are shown in table $I I$.

Heritability estimates ranged from 0.32 to 0.40 for yields and from 0.50 to 0.60 for solid contents. For both yields and contents, the estimates of genetic variability and the corresponding genetic coefficient of variation were higher for fat than for protein. Heritability estimates were also higher for FY and FC than for PY and PC, respectively, in the Saanen breed, but not in the Alpine breed.

Heritability estimates were similar to previous results for the Alpine and Saanen breeds [3], although the samples and the method of analysis differed. For other goat populations (other breeds or other environmental conditions), the reported heritabilities for yields varied from about $0.20[9,12]$ to about 0.60 [6] while estimates from test-date models were about 0.3 [11].

Previous reports and this study focused on the global genetic variability of dairy traits in goats, thus including both polygenic and major gene effects ( $\alpha$ s1-casein polymorphism, $[1,2]$ ). The $\alpha$ s1-casein polymorphism might explain part of the apparent differences in genetic parameters between breeds. Milk composition is influenced by the $\alpha$ s1-casein genotype of goats, different alleles being associated with different rates of $\alpha$ s1-casein synthesis. Allelic frequencies differ between breeds, with a higher frequency of 'extreme' alleles in the Alpine breed [5]. Higher genetic variability and the resulting higher heritability value for PC in the Alpine breed might thus result from its more variable $\alpha$ s1-casein polymorphism.

\subsection{Correlations between traits}

Strong positive correlations between yields were observed in both breeds (see table $I I I$ ), with genetic correlations between milk and fat yields being the lowest $(+0.76)$. The genetic correlation between fat and protein contents were also rather high, up to +0.61 in the Alpine breed. The negative correlations between milk and solid contents, whether phenotypic or genetic, were moderate for protein and low for fat. The genetic opposition between milk and FC was 
Table III. Estimates of phenotypic and genetic correlations (above and below diagonal, respectively) \pm estimates of the corresponding standard errors.

\begin{tabular}{|c|c|c|c|c|c|}
\hline & Milk & PY & $\mathrm{PC}$ & FY & $\mathrm{FC}$ \\
\hline \multicolumn{6}{|c|}{$\begin{array}{l}\text { a) Alpine } \\
\text { breed }\end{array}$} \\
\hline $\begin{array}{l}\text { Milk } \\
\text { PY } \\
\text { PC } \\
\text { FY } \\
\text { FC }\end{array}$ & $\begin{array}{r}+0.887 \pm 0.006 \\
-0.284 \pm 0.024 \\
+0.765 \pm 0.012 \\
-0.177 \pm 0.027\end{array}$ & $\begin{array}{c}+0.933 \\
+0.186 \pm 0.027 \\
+0.858 \pm 0.008 \\
+0.113 \pm 0.026\end{array}$ & $\begin{array}{c}-0.384 \\
-0.038 \\
+0.141 \pm 0.027 \\
+0.614 \pm 0.016\end{array}$ & $\begin{array}{c}+0.849 \\
+0.884 \\
-0.106 \\
+0.491 \pm 0.022\end{array}$ & $\begin{array}{l}-0.159 \\
+0.014 \\
+0.492 \\
+0.377\end{array}$ \\
\hline \multicolumn{6}{|c|}{$\begin{array}{l}\text { b) Saanen } \\
\text { breed }\end{array}$} \\
\hline $\begin{array}{l}\text { Milk } \\
\text { PY } \\
\text { PC } \\
\text { FY } \\
\text { FC }\end{array}$ & $\begin{array}{l}+0.923 \pm 0.005 \\
-0.288 \pm 0.032 \\
+0.764 \pm 0.014 \\
-0.099 \pm 0.034\end{array}$ & $\begin{array}{c}+0.952 \\
+0.099 \pm 0.038 \\
+0.831 \pm 0.010 \\
+0.102 \pm 0.032\end{array}$ & $\begin{array}{c}-0.398 \\
-0.111 \\
+0.079 \pm 0.036 \\
+0.512 \pm 0.023\end{array}$ & $\begin{array}{c}+0.855 \\
+0.877 \\
-0.163 \\
+0.557 \pm 0.025\end{array}$ & $\begin{array}{l}-0.122 \\
-0.015 \\
+0.410 \\
+0.388\end{array}$ \\
\hline
\end{tabular}

lowest in the Saanen breed $(-0.10)$, and, consequently, the genetic correlation between FC and FY was highly positive in this breed $(+0.56)$. As in Boichard et al. [3], we observed a low genetic antagonism between milk yield and FC, with high genetic associations between FC and FY. The phenotypic antagonism and the genetic association between FC and PY or PC and FY were low in both breeds.

Although correlations were similar for both breeds, point estimates suggest that the potential for genetic progress in PC and PY might be somewhat higher in the Alpine breed and the potential for joint progress in FC and milk and fat yields might be somewhat higher in the Saanen breed: in the Alpine breed, both heritability and genetic variability for $\mathrm{PC}$ were higher, and both the genetic association between $\mathrm{PC}$ and $\mathrm{PY}$ and the genetic opposition between milk yield and $\mathrm{FC}$ were stronger.

\section{CONCLUSION}

This study, using an animal model and recently collected data, confirmed previous estimates of genetic parameters for the Alpine and Saanen breeds. The low antagonism between milk yield and fat content found in this study indicates that losses in genetic gains for yields will be relatively low if fat content is included in the new selection objective.

\section{ACKNOWLEDGEMENTS}

We acknowledge Caprigene France for financial support and the CTIG for providing the data. 


\section{REFERENCES}

[1] Barbieri E., Manfredi E., Bouillon J., Ricordeau G., Elsen J.M., Mahé F., Grosclaude F., Influence of the polymorphism of the $\alpha$ s1-casein on goat dairy performances, 5th World Congr. Genet. Appl. Livestock Production 19 (1994) 344347.

[2] Barbieri M.E., Manfredi E., Elsen J.M., Ricordeau G., Bouillon J., Grosclaude F., Mahé M.F., Bibé B., Influence du locus de la caséine $\alpha$ s1 sur les performances laitières et les paramètres génétiques des chèvres de race Alpine, Genet. Sel. Evol. 27 (1995), 437-450.

[3] Boichard D., Bouloc N., Ricordeau G., Piacère A., Barillet F., Genetic parameters for first lactation dairy traits in the Alpine and Saanen goat breeds, Genet. Sel. Evol. 21 (1989) 205-215.

[4] Díaz C., Carabaño M.J., Hernàndez D., Connectedness in genetic parameters estimation and BV prediction, 46th Annual Meeting of the European Association for Animal Production, Prague, Czech Republic, 1995, p. 8 (abstract).

[5] Grosclaude F., Ricordeau G., Martin P., Remeuf F., Vassal L., Bouillon J., Du gène au fromage : le polymorphisme de la caséine $\alpha \mathrm{s} 1$ caprine, ses effets, son évolution, INRA Prod. Anim. 7 (1994) 3-19.

[6] Kennedy B.W., Finley C.M., Bradford G.E., Phenotypic and genetic relationship between reproduction and milk production in goats, J. Dairy. Sci. 65 (1982) 2373-2383.

[7] Lebœuf B., Manfredi E., Boue P., Piacère A., Brice G., Baril G., Broqua C., Humblot P., Terqui M., Artificial insemination of dairy goats in France, Livest. Prod. Sci. 55 (1998) 193-203.

[8] Neumaier A., Groeneveld E., Restricted maximum likelihood estimation of covariances in sparse linear models, Genet. Sel. Evol. 30 (1998) 3-26.

[9] Rabasco A., Serradilla J.M., Padilla J.A., Serrano A., Genetic and nongenetic sources of variation in yield and composition of milk of Verata goats, Small Rumin. Res. 11 (1993) 151-161.

[10] Schaeffer L.R., Disconnectedness and variance component estimation, Biometrics 31 (1975) 969-977.

[11] Schaeffer L.R., Sullivan B.P., Genetic evaluation of dairy goats using test day yields, 5th World Congr. Genet. Appl. Livestock Production 18 (1994) 182-185.

[12] Wiggans G.R., Animal model evaluation of dairy goats for milk, fat, and protein yields with crossbred animals included, J. Dairy Sci. 72 (1989) 2411-2416. 